\title{
On the Relationship between Iranian EFL Teachers' Commitment to Professional Ethics and their Students' Self-Esteem
}

\author{
Nooshin Salehnia \\ English Department, Torbat-e Heydarieh Branch, Islamic Azad University, Torbat-e Heydarieh, Iran \\ Email: nsalehnia66@gmail.com \\ Hamid Ashraf* \\ English Department, Torbat-e Heydarieh Branch, Islamic Azad University, Torbat-e Heydarieh, Iran \\ Emails: h.ashraf@iautorbat.ac.ir; hamid.ashraf.elt@gmail.com
}

Doi:10.5901/mjss.2015.v6n5s1p135

\section{Abstract}

Despite the importance of professional ethics for organizations, this matter has not been investigated much in the field of English language teaching. The purpose of the present study is to investigate the relationship between EFL teachers' commitment to professional ethics and students' self-esteem. A total of 357 teachers and 1785 students (at upper-intermediate and advanced levels) participated in this research. The instrumentation for assessing teacher's professional ethics was based on studies by Murray (1996) and Motallebifard, NaveEbrahim, and Mohsenzadeh, (2011). Also, to assess the students' selfesteem the Persian version of the Rosenberg Self-Esteem Scale (RSES) by Rajabi, and Bohlol (2007) was used. In the present study, descriptive statistics of each principle was run. Also, Pearson Product-moment Correlation analysis was used to compute the results. The results reveal that there is a positive significant relationship between most of the professional ethics principles especially teachers' student professional development principle and students' self-esteem. By the increase of commitment of teachers to professional ethics their students' self-esteem has increased.

Keywords: Professional Ethics, Students' Self-Esteem, EFL Teachers

\section{Introduction}

Nowadays, professional ethics and commitment to this important concept has a vital role in each organization. Professional ethics plays a key role especially in education systems, and creates a mutual understanding between each person as an employee with others. There are some principles in some developed countries for teachers in educational system and these are named "professional ethics". The notion of professional ethics is more developed recently especially in the Western countries. Also, it is crystal clear that teachers play a key role in each education system. Their roles are at least in two major areas, providing a stimulating learning environment to ensure that all of the students achieve their potential, and behaving in an appropriate way. Moreover, teachers can affect learners' emotions, feelings and their lives consciously or subconsciously. As Williams and Burden (2004) in their book entitled "Psychology of Language Teachers" stated, humanistic approach highlights the importance of the inner world of the learners, thus the learners' emotion, feelings, thoughts and reflections are considered as the main factors in the learning process.

It seems a number of teachers are interested to know what the most constructive professional ethics principles and rules are around the world and Iran is not an exception. Promoting ethics in the organization not only creates a favorable environment for increased productivity, but also has a more effective role in society.

As already mentioned, it seems that professional ethics principles have vital role in any education system particularly in teaching English language. Not only is knowing about professional ethics and morality an essential part in education system, but also it can perform the crucial role in other fields of study, such as business, management, and many other sciences. While many attempts have been made to determine some principles for professional ethics and rules especially in developed countries in education system for teachers in classrooms, few studies exist in EFL domain for English language teachers' professional ethics. Because of lack of attention to this crucial subject, the researchers tried to construct a useful scale to evaluate EFL teachers' commitment and get them familiar with the necessary professional ethics principles. The researchers anticipated the results of findings may provide some specific professional ethics principles to improve EFL teachers' attempts in English classrooms. Also, the outcomes of this research will be 
beneficial for every person in field of education such as EFL/ESL teachers, learners, researchers, authors.

\section{Research Question and Research Hypothesis}

Based on what was mentioned above, the present study makes an attempt to investigate the following research question:

1. Is there any significant relationship between Iranian EFL teachers' commitment to professional ethics and their students' self-esteem?

Based on the research question, the following hypothesis was formulated:

1. There is no significant relationship between Iranian EFL teachers' commitment to professional ethics and their students' self-esteem.

\section{Literature Review}

Historically, the concepts of ethics refer to classification such as good-bad, beautiful-ugly; true-false which the community members within the same values to the human behavior and relations have added. Ethics deals with human behavior. Ethics can be thought of as also a framework conveying philosophy, moral problems and moral judgments (Mehalu, 2011).

Carr (2013) mentioned that as a profession, teachers are required to have both pedagogical knowledge of what it means to practice as well as an awareness of their legal obligation to students and the educational community. Also, Wandira (1986) believed teacher professionalism meant a teacher adhering to the teaching code of conduct. Therefore, teacher professionalism affects the role of the teacher and his or her pedagogy, which in turn affects the student's ability to learn effectively.

Regarding school moral atmosphere, Beem, Brugman, Host and Tavecchio (2004) in a research about students' perception of school moral atmosphere from moral culture to social competence, concluded that students' perception of moral atmosphere in normal secondary schools have a strong individual flavor. The authors claimed that perceived moral atmosphere should not be regarded primarily as a shared perspective among students within a school like a moral school culture, but as an instance of the social competence of the individual student.

Moreover, Imanipour (2012) studied the ethical principles in education by a qualitative research. According to her findings, every organization has a set of moral codes to suit its professional structure called professional ethics. This study had two main conclusions; first, teacher should know the most effective ways in transferring positive moral values, and second, teacher should perform his educational responsibilities well.

During the last two decades students' self-esteem and its relationship with other variables has been constantly mentioned in teaching area .In relation to self-esteem, attempts have been made to define it theoretically and to work on its relationship with other constructs or other way around. As one the recent ones in Iranian context is the study by Saadat, Ghaesemzadeh, and Soleimani (2011). They did a research on self-esteem in Iranian university students and its relationship with academic achievement. Based upon the findings of this research, out of five domains of self-esteem, only the academic and family self-esteem have a meaningful relationship with the educational progress of the students.

The study by Koosha, Ketabi, and Kassaian (2011) is also related to the same field. They carried out a research on the effects of self-esteem, age and gender on speaking skill. The results indicated that there is a significant relationship between self-esteem and speaking skill. Also, there was a reverse relationship between age and speaking skills. As it was indicated, the levels of learners' self-esteem have a significant influence on the students' speaking and their fluency. Therefore, teachers should consider their students' level of self-esteem and they should try to increase it as much as possible because this matter affects the students' performance.

In another correlational study, Heidarisoureshjani and Naseri(2011) examined the relationship between selfesteem, proficiency level, and the reading ability of Iranian EFL language learners. The result showed that there was a weak significant relationship between the learners' self-esteem and their reading performance. Also, there was a strong significant relationship between the proficiency level of language learners and their self-esteem.

Another relevant study is the one by Rashidi, Yamini, and Shafiei (2011). They carried out a study on the oral communication apprehension and affective factors, self-esteem and introversion/extroversion. They intended to suggest a causal model of factors that would forecast oral communication apprehension of Iranian learners of EFL. In this study some variables were considered such as learners' self-esteem and introversion/extroversion, their gender and proficiency level and also their oral communication apprehension. The results indicated that extroversion was to be the strongest predictor of oral communication apprehension. Also, the researchers found that females and the lowest proficiency students experience a significantly higher level of oral communication apprehension. 
Ethical principles ignorance may cause many problems for all organizations and also create barriers for members' development in societies. Also, ethics affects the organization activities, results, and also its productivity. Professional ethics and commitment to ethical principles are inseparable parts in each community and each organization should make these principles crystal clear for all members. As already mentioned, there are several existing ethics principles in different fields of study, but none of them are especially for EFL teachers in institutions. It is really important for teachers, to get better understanding of how much they pay attention to professional ethics and morality in order to increase students' self-esteem in English classes among learners. Also, in Iran no study on the relationship between Iranian EFL teachers' commitment to professional ethics and students' self-esteem has been found.

\section{Methodology}

\subsection{Participants and setting}

A total of 357 English language teachers (198 females and 159 males) were selected randomly from various English language institutes of Iran. This sample size has been calculated based on Morgan's table (Morgan, 1970 "Determining Sample Size for Research Activities", Educational and Psychological Measurement). This study sample size should be 357 teachers (Considering the $95 \%$ of the level of confidence and 0.05 degree of accuracy). All of the participants were selected from private English language institutions in Tehran, Mashhad, Gorgan, Bojnord, Sabzevar, Neyshabour, Torbat-e Heydarieh and Ferdows. The participants were asked to respond to a scale of Iranian EFL teachers' commitment to professional ethic with 10 principles and 32 items. It was estimated that the whole number of English language institutes is1000 in Iran and if each English language institute had an average of 5 upper-intermediate and advanced teachers, the population of his study included approximately 5000 teachers. The participants comprised males and females holding Bachelor, Master and PhD degrees. The range of their ages was between 20 and 60 with different years of experiences. In this research for each EFL teacher, researchers considered 5 students due to the problem of collecting data from students and it meansfor 357 teachers, indeed 1785 students participated. All learners were only upper-intermediate and advanced levels based on the institute classification, both males and females were selected and also the learners were adults and young adults. Because of a wide range of students from beginners to advanced level, researcher considered only these levels to get the best results.

\subsection{Instruments}

The questionnaires employed in this study measure the relationship between EFL teachers' commitment to professional ethics and students' self-esteem. Two questionnaires were used in this study: EFL teachers' commitment to professional ethics and the Persian version of the Rosenberg Self-Esteem Scale (RSES) by Rajabi, and Bohlol (2007).

\subsubsection{EFL Teachers' Commitment to Professional Ethics Questionnaire}

The first questionnaire was designed based on what was done by Murray, et al. (1996) and Motallebifard, NaveEbrahim, and Mohsenzadeh, (2011) which were carried out to study professional ethics principles for university teachers. English language teachers' commitment to professional ethics questionnaire (see Appendix) was researchers' made questionnaire. The first version of the questionnaire was given to some specialists to judge its content validity. Through this way, some items were modified, others were deleted and also some principles were added until the researchers came up with the final draft of 10 principles that consisting 32 items. The revised version of the questionnaire was handed to a number of English teachers as a pilot study to check the probable difficulties they may face. Then, the second revised version was conducted again to a number of English teachers to estimate its reliability. The reliability calculated with Cronbach alpha was 0.84. These items are rated on a 5-point Likert scale from (1) never to (5) always. There are 10 principles which represent the underlying structure of teachers' commitment to professional ethics. These principles are as follow:

Principle 1: Content competence, Principle 2: Pedagogical competence, Principle 3: Dealing with sensitive topics, Principle 4: Student professional development, Principle 5: Dual relationship with students, Principle 6: Respect for colleagues, Principle 7: Valid assessment of students, Principle 8: Respect for institution, Principle 9: Respect for class, Principle 10: Confidentiality with Students and Collaboration with parents. The underlying principles indicated that the items of the questionnaire can cover many different characteristics that a teacher should have as a commitment to professional ethics. 


\subsubsection{Rosenberg Self-Esteem Scale}

The second instrument was the Rosenberg Self-Esteem Scale (RSES) which consists of 10 items. These items are rated on a 4-point Likert scale from (1) strongly disagree to (4) strongly agree. This measure has an internal consistency which ranges from 0.77 to 0.88 . The test-retest reliability also ranges from 0.82 to 0.85 and an internal consistency reliability of 0.88 (Rosenberg, 1965). However, in this study the researcher used the Persian version of the Rosenberg Self-Esteem Scale (RSES) by Rajabi, and Bohlol (2007) and the reliability was estimated through Cronbach alpha (0.84).

\subsection{Procedure}

In the present study, the researchers tried to follow some steps as follow. First, the researchers attempted to investigate the professional ethics principles based on the previous studies. Second, the first version of the questionnaire was handed to a number of English teachers as a pilot study to check the probable difficulties they may face. The reliability calculated with Cronbach alpha was 0.84 . Also, in order to examine the construct validity of the questionnaire, two types of factor analysis, namely Exploratory Factor Analysis (EFA) and Confirmatory Factor Analysis (CFA) were used. Furthermore, the researcher tried to explain how the participants can fill out the questionnaires in a correct way. The study was conducted in language institutes in Iran. It started in June, 2014. Gathering data took three months. In present study, 357 participants as sample of Iranian EFL teachers participated. The probable needed time for filling out teachers' professional ethics questionnaire was about 15 minutes. Also, for each English teacher 5 students were asked to fill out questionnaires distributed to them. The researchers gathered data through spreading questionnaires, and because the researchers considered a questionnaire for learners too, it wasn't possible to gather data through web because the students weren't available at that time. The probable needed time for filling out teachers' professional ethics questionnaire it was about 15 minutes, and for students' self-esteem questionnaire was 5 minutes. Also, the researchers tried to explain how the participants can fill out the questionnaires in a correct way. The data collected were summarized in SPSS software. Then, the correlation between these two variables was calculated by the use of appropriate formulas.

Since the purpose of each design is to avoid possible errors in order to share findings with others, this study adopted quantitative method. Correlational and factorial designs were used according to determined variables. This study was going to investigate any significant relationship between the variable of EFL teachers' professional ethics and the other variable of students' self-esteem. Also, the enquiry aimed to find out whether teachers' commitment to professional ethics can predict the students' self-esteem.

\section{Results and Data Analyses}

In the current study, as mentioned before, an attempt was made to find answer to the only research question concerning the relationship between Iranian EFL teachers' commitment to professional ethics and students' self-esteem. Suitable statistical analyses were followed to obtain the response for the only question. Also, descriptive statistics for the scales used in this study would be reported. Following this, the correlations between EFL teachers' professional ethics and their learners' self-esteem are reported and discussed.

\subsection{Descriptive Statistics}

A demographic information section was designed by the researcher to control factors that might have an effect upon the participants' responses.

\subsubsection{Teachers' Demographic Analyses}

The professional ethics questionnaire was designed to control the participant's teaching years of experience, levels they teach, gender, age, educational degree, their major of study. In this part the researcher tried to calculate frequency and percent of the responses for each of these parts (Table 1). 
Table 1. Teachers' Demographic Analyses

\begin{tabular}{lccc}
\hline & & Frequency & Percentage \\
\hline \multirow{3}{*}{ Years of Teaching Experience } & Below 5 & 94 & 26.33 \\
\cline { 2 - 4 } & $5-10$ & 142 & 39.78 \\
\cline { 2 - 4 } & $11-15$ & 69 & 19.33 \\
\cline { 2 - 4 } Level/s the Teacher Teach & Above 15 & 52 & 14.56 \\
\hline \multirow{2}{*}{ Teachers' Gender } & Upper-intermediate & 214 & 60 \\
\cline { 2 - 4 } & Advanced & 143 & 40 \\
\hline \multirow{3}{*}{ Teachers' Age } & Male & 159 & 44.53 \\
\cline { 2 - 4 } & Female & 198 & 55.47 \\
\cline { 2 - 4 } & $20-29$ & 128 & 35.85 \\
\cline { 2 - 4 } Teachers' Degree & $30-39$ & 96 & 26.90 \\
\cline { 2 - 4 } & $40-49$ & 76 & 21.29 \\
\hline \multirow{2}{*}{ Teachers' Major of Study } & $50-59$ & 190 & 15.96 \\
\cline { 2 - 4 } & Bachelor & 161 & 45.23 \\
\hline Total Participants of Teachers & MA & 6 & 1.68 \\
\hline
\end{tabular}

As Table 1 indicates a total of 357 English language teachers included 159 males (44.53\%) and 198 females (55.47\%), they taught at two levels: 214 Upper-intermediate (60\%) and 143 Advanced (40\%), teachers had different academic majors: English teaching 193 (54.06\%), English literature 107 (29.98\%), English translation57 (15.96\%). They also had different degrees: bachelor 190 (53.23\%), MA 161 (45.09\%), and PhD 6 (1.68\%). Teachers were in different age ranges as: (20-29) 128 (35/85\%), (30-39) 96 (26.90\%), (40-49) 76 (21.29\%), and (50-59) 57 (15.96\%). They had different years of teaching experience: (below 5) 94 (26.33\%), (5-10) 142 (39.78\%), (11-15) 69 (19.33\%), and (above 15) 52 (14.56\%).

\subsubsection{Students' Demographic Analyses}

Also, Rosenberg self-esteem questionnaire was used. It consisted of some demographic information like students' age, gender, level. (Table 2).

Table 2. Students' Demographic Analyses

\begin{tabular}{|c|c|c|c|}
\hline & & Frequency & Percentage \\
\hline \multirow{2}{*}{ Students' Level } & Upper-intermediate & 1071 & 60 \\
\hline & Advanced & 714 & 40 \\
\hline \multirow{2}{*}{ Students' Gender } & Male & 643 & 36.03 \\
\hline & Female & 1142 & 63.97 \\
\hline \multirow{3}{*}{ Students' Age } & $15-24$ & 803 & 45 \\
\hline & $25-34$ & 946 & 53 \\
\hline & $35-44$ & 36 & 2 \\
\hline \multicolumn{2}{|c|}{ Total Participants of Learners } & 1785 & 100 \\
\hline
\end{tabular}

As Table 2 indicates a total of 1785 English learners included 643 males (36.03\%) and 1142 females (63.97\%), they were at two levels 1071 Upper-intermediate (60\%), and 714 Advanced (40\%), also learners were in different age ranges such as (15-24) 803 (45\%), (25-34) 946 (53\%), and (35-44) 36 (2\%).

\subsubsection{The Means of Factors Obtained from Descriptive Statistics}

Descriptive statistics including mean, and standard deviation for EFL Teachers' Professional Ethics Questionnaire was calculated (see Table 3). 
The results from descriptive statistics (Table 3) shows that Iranian EFL teachers in English institutes are more committed to professional ethics to Pedagogical Competence principle (mean 17.77) and Student Professional Development principle (mean 17.50).

Table 3. The Means of Factors Obtained from Descriptive Statistics

\begin{tabular}{lccccc}
\hline & N & Mean & Std. Deviation & & \\
\hline Content Competence & 357 & 16.85 & 2.33 \\
Pedagogical Competence & & 357 & 17.77 & 1.79 \\
Dealing with Sensitive Topics & & 357 & 8.57 & 1.53 \\
Student Professional Development & & 357 & 17.50 & 2.49 \\
Dual Relationship with Students & 357 & 14.40 & 1.90 \\
Respect for Colleagues & 357 & 9.60 & 1.79 \\
Valid Assessment of Students & 357 & 11.70 & 2.17 \\
Respect for Institution & 357 & 13.52 & 1.51 \\
Respect for Class & 357 & 13.75 & 1.45 \\
Confidentiality with Students and Collaboration with Parents & 357 & 8.69 & 1.32 \\
Valid N & 357 & & \\
\hline
\end{tabular}

As Table 3 indicates, Iranian EFL teachers in English institutes are committed to professional ethics principles from the most to the least as follows:1) Pedagogical Competence principle (mean 17.77), 2) Student Professional Development principle (mean 17.50), 3) Content Competence principle (mean 16.85), 4) Dual Relationship with Students principle (mean 14.40), 5) Respect for Class principle (mean 13.75), 6) Respect for Institution principle (mean 13.52), 7) Valid Assessment of Students principle (mean 11.70), 8) Respect for Colleagues (mean 9.60), 9) Confidentiality with Students and Collaboration with Parents principle (mean 8.69), 10) Dealing with Sensitive Topics principle (mean 8.57). It should be noted that the maximum score calculated in this part was 20 .

\subsection{Correlation}

In order to answer the research question that was to measure whether there is a relationship between Iranian EFL teachers' commitment to professional ethics and their students' self-esteem, Pearson Product-Moment correlation formula was used. Results can be seen in Table 4.

\subsubsection{Correlation between Iranian EFL teachers' commitment to professional ethics and students' self-esteem}

To see the relationship between EFL teachers' commitment to professional ethics and students' self-esteem correlation was used.

Table 4. Correlation between Teachers' Professional Ethics and Students' Self-esteem

\begin{tabular}{|c|c|c|c|c|c|}
\hline \multirow{4}{*}{$\begin{array}{l}\text { Self-Esteem with Professional } \\
\text { Ethics Principles }\end{array}$} & $\begin{array}{c}\text { Content } \\
\text { Competence }\end{array}$ & $\begin{array}{l}\text { Pedagogical } \\
\text { Competence }\end{array}$ & $\begin{array}{l}\text { Sensitive } \\
\text { Topics }\end{array}$ & $\begin{array}{l}\text { Student Professional } \\
\text { Development }\end{array}$ & Dual Relationship with Students \\
\hline & .02 & $.14^{*}$ & .03 & $.28^{\star *}$ & $.19^{\star \star}$ \\
\hline & $\begin{array}{l}\text { Respect for } \\
\text { Colleagues }\end{array}$ & $\begin{array}{l}\text { Valid Assessment of } \\
\text { Students }\end{array}$ & $\begin{array}{l}\text { Respect for } \\
\text { Institution }\end{array}$ & Respect for Class & $\begin{array}{c}\text { Confidentiality with Students and } \\
\text { Collaboration with Parents }\end{array}$ \\
\hline & $.23^{\star \star}$ & $.13^{*}$ & .01 & $20^{* *}$ & $.18^{\star \star}$ \\
\hline
\end{tabular}

$$
{ }^{*}=p<.05 \quad{ }^{* *}=p<.01
$$

As Table 4 indicates, self-esteem has a positive significant correlation with seven of the EFL teachers' commitment to professional ethics subscales as follows. Learners' self-esteem had a positive relationship with these seven principles: pedagogical competence $(r=.14, p<.05)$, student professional development $(r=.28, p<.05)$, dual relationship with students $(r=.19, p<.05)$, respect for colleagues $(r=.23, p<.05)$, valid assessment of students $(r=.13, p<.05)$, respect for class $(r=.20$, $p<.05)$, confidentiality with Students and collaboration with parents $(r=.18, p<.05)$. Among these seven principles, student professional development principle had the strongest and highest correlation with students' self-esteem $(r=.28, p<.05)$, while valid assessment of students had the lowest correlation with students' self-esteem $(r=.14, p<.05)$. Also, no significant relation was found between learners' self-esteem with content competence $(r=.02, p>05)$, dealing with 
sensitive topics ( $r=.03, p>.05)$, and respect for institution ( $r=.01, p>.05)$.

Based on the results, the null hypothesis was rejected especially in these seven principles: pedagogical competence, student professional development, dual relationship with students, respect for colleagues, valid assessment of students, respect for class, confidentiality with students and collaboration with parents. All of these seven principles had a significant relationship with students' self-esteem. It means that by the increase of these factors: pedagogical competence student professional development, dual relationship with students, respect for colleagues, valid assessment of students, respect for class, confidentiality with students and collaboration with parents, students' self-esteem increased respectively. Therefore, there is a positive significant correlation between most of the professional ethics principles and students' self-esteem. Based on the results, there is no significant relationship between learners' self-esteem with content competence, dealing with sensitive topics, and respect for institution principles.

\section{Discussion}

This study was intended to investigate the relationship between Iranian EFL teachers' commitment to professional ethics and students' self-esteem. All of the previous studies only worked on qualitative results, it means that the researchers just provided some determined principles in professional ethics for teachers. And none of them worked on quantitative results in this subject. In fact, the ethical principles of the current study were in line with other researches (Murray, Gillese, Lennon, Mercer, and Robinson, 1996; Motallebifard, NaveEbrahim, and Mohsenzadeh, 2011; Mohajeri, Sharif, and Mohajeri, 2012). On the contrary, the present research worked on quantitative results and it worked on this crucial issue only for education systems not the other fields of study or other situations. In this study according to obtain results: there was a positive correlation between most of the professional ethics principles and students' self-esteem.

\section{Conclusions and Pedagogical Implications}

The purpose of the present study was to examine the relationship between EFL teachers' professional ethics and students' self-esteem. By paying attention to the obtained results, self-esteem should be taken into consideration as an important affective factor in each English class. According to obtained results, teachers' commitment to student professional development principle had the strongest, highest and most positive correlation with students' self-esteem. Valid assessment of students had the lowest correlation with students' self-esteem. Also, no significant relation was found between learners' self-esteem and content competence, dealing with sensitive topics, and respect for institution.

Results of the present study provide teachers and researchers with theoretical and pedagogical implications to improve professional ethics in all EFL teachers and also in their classes. Results of the analysis indicated that commitment to professional ethics among EFL teachers is highly related to students' self-esteem especially in seven principles. This finding has some implications. Teachers should be aware of this important issue, because the importance of knowing about professional ethics can affect students' self-esteem. Teachers should pay attention to all professional ethics principles and should consider them in their classes. Knowing about these principles may enhance self-esteem among all students in their classes. Besides, the outcomes of this study can help teachers to perceive their students' situations better. Teachers should be aware of the importance of professional ethics in education and they should pay attention to this concept during their teaching process. Also, managers and institutions should consider and determine some rules based on these essential principles to improve English language learning process.

\section{Suggestions for Further Research}

In the present study, a researchers' made questionnaire (EFL teachers' commitment to professional ethics) was filled out by teachers about their commitments to this essential element in teaching domain. The following suggestions can be fruitful lines of inquiry:

In this study, the researcher examined the relationship between EFL teachers' professional ethics and students' self-esteem among language institute learners. Further research can explore the role of these two variables in public schools and compare them with the results of the present study. It might help to get a better understanding of the underlying structure of professional ethics views in public schools and private language institutes. It is really good for educational systems to hold a course of study based on commitment to professional ethics for teachers. This study considered two levels (upper-intermediate and advanced) both for teachers and students. Other studies can be done at elementary, pre-intermediate, and intermediate levels both for teachers and students. The present study used Rosenberg's self-esteem questionnaire that doesn't have different subscales for examining students' self-esteem. Other 
studies can use other instrument for measuring students' self-esteem like the Coopersmith's questionnaire that consists of some subscales. Also, others may find some different results by using this kind of questionnaire instead of Rosenberg's one.

\section{References}

Beem, L., Brugman, D., Høst, K., \&Tavecchi, L.W. (2004). Students' perception of school moral atmosphere: From moral culture to social competence. A generalizability study. European Journal of Development Psychology, 1(2), 171 -192.

Carr, D. (2013). Professionalism and ethics in teaching (Vol.2).Routledge.

Heidarisoureshjani, K., \& Naseri, N. (2011).An investigation into the relationship between self-esteem, proficiency level, and the reading ability of Iranian EFL language learners. Journal of Language Teaching and Research, 2(6), 1312-1319. doi:10.4304/jitr.2.2. $1312-1319$

Imanipour, M. (2012).Ethical principles in education. Iranian Journal of Medical Ethics and History, 5(6), $27-41$.

Koosha, B., Ketabi, S., \& Kassaian, Z. (2011).The effects of self-esteem, age and gender on the speaking skills of intermediate university EFL learners. Theory and Practice in Language Studies, 1(10), 1328-1337. doi: 10.4301/tpls.1.10

Mehalu, K. (2011). "Social Responsibility and Managerial Ethics: A Focus on MNCs" 3. Global Drucker Forum, Vienna.

Mohajeri, M., Sharif, M., \&Mohajeri, A. (2012).Investigating the relationship between elementary school teachers' professional competence and academic performance of students in Isfahan. Quarterly Journal of New Approaches to Learning. 7(1), 27-48.

Motallebifard, A., NaveEbrahim, A., \& Mohsenzadeh, F. (2011).On the relationship between ethical and professional markers in education and teaching context regarding to MA students. Quarterly journal of Morality in science and technology, 6(4), 9-16.

Murray, H., Gillese, E., Lennon, M., \& Robinson, M. (1996). Reflecting on the Practice of Teaching. University of Manitoba.

Rajabi, Gh., R., Bohlol, N., (2007). Assess the reliability and validity of the Rosenberg self-esteem scale ai first year students of Shahid Chamran University. University of Isfahan Journals System New Educational Approaches. 3(2):33-48.

Rashidi, N., Yamini, M., \& Shafiei, E. (2011). Oral communication apprehension and affective factors: Self-esteem and Introversion/ Extroversion. Journal of English Language Teaching and Learning, 5(7), 145-174.

Saadat, M., Ghaesemzadeh, A., \&Soleimani, M. (2011).Self-esteem in Iranian university students and its relationship with academic achievement. Procedia- Social and Behavioral Sciences, 31, 10-14. doi:10.1016/j.sbspro.2011.12.007

Wandira, A. (1986). Indigenous education in Uganda (A study of the Practice and Purpose of indigenous education in Uganda). Department of Education, Makerere University.

Williams, M., \& Burden, R.L. (2004). Psychology of Language teachers: A social constructivist approach. Ernst Klett Sprachen.

\section{Appendix}

\section{EFL Teachers' Professional Ethics Questionnaire}

Dear respondent. This survey is designed to explore EFL Teachers' commitments to Professional Ethics. We are really thankful to your real responses. The information you reveal to us through this questionnaire is kept confidential and would be used for research purposes.

\section{A. Teachers' information: Please mark the part that best matches your status.}

\begin{tabular}{|l|l|l|l|}
\hline 1 & Years of teaching experience & Below $5 \square$ \\
\hline 2 & Level/s you teach at (now) & Upper-intermediate \\
\hline 3 & Gender & Male \\
\hline 4 & Age & Degree & Bachelor \\
\hline 6 & Your Major of study & Teaching English $\square$ \\
\hline 7 & Courses passed or studies done in professional ethics & Yes $\square$ \\
\hline
\end{tabular}

\section{B. Please mark the part that best matches your status. There is no wrong or right answer.}

\begin{tabular}{|c|c|c|c|c|c|c|}
\hline & & 㐫 & 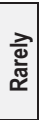 & 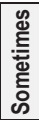 & 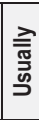 & 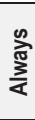 \\
\hline 1 & The courses I teach match my field of study. & 1 & 2 & 3 & 4 & 5 \\
\hline & I try to use up-to-date materials in my classes. & 1 & 2 & 3 & 4 & 5 \\
\hline 3 & I try to use some extra materials (supplementary) in my classes. & 1 & 2 & 3 & 4 & 5 \\
\hline 4 & I try to create challenges in the topics I teach to make my students think and form questions. & 1 & 2 & 3 & 4 & 5 \\
\hline 5 & I use an appropriate methodology in my classes. & 1 & 2 & 3 & 4 & 5 \\
\hline & I use a lesson plan for my teaching. & 1 & 2 & 3 & 4 & 5 \\
\hline
\end{tabular}




\begin{tabular}{|c|c|c|c|c|c|c|}
\hline & I try to be accountable to my duties as a teacher. & 1 & 2 & 3 & 4 & 5 \\
\hline 8 & I try to up-to-date my knowledge for my classes. & 1 & 2 & 3 & 4 & 5 \\
\hline 9 & I am careful of not using sensitive topics in my classes. & 1 & 2 & 3 & 4 & 5 \\
\hline 10 & I try to consider my students' differences in classroom as a teacher. & 1 & 2 & 3 & 4 & 5 \\
\hline 11 & I try to make my students independent. & 1 & 2 & 3 & 4 & 5 \\
\hline 12 & I try to make my teaching / classes interesting to students. & 1 & 2 & 3 & 4 & 5 \\
\hline 13 & I feel much concerned with my students' questions and answers. & 1 & 2 & 3 & 4 & 5 \\
\hline 14 & I feel much concerned with my students to help them understand the topic I teach. & 1 & 2 & 3 & 4 & 5 \\
\hline 15 & I may have an instrumental view to my students i.e. the benefits they (or their parents) can provide me are important. & 1 & 2 & 3 & 4 & 5 \\
\hline 16 & I form an equal relationship with all of my students in my classes. & 1 & 2 & 3 & 4 & 5 \\
\hline 17 & I form a professional relationship (not a personal one) with my students in my classes. & 1 & 2 & 3 & 4 & 5 \\
\hline 18 & I form a professional relationship (not a personal one) with my students in office hours. & 1 & 2 & 3 & 4 & 5 \\
\hline 19 & I try to create a situation that my students can trust me in classroom. & 1 & 2 & 3 & 4 & 5 \\
\hline 20 & When I face a problem in my classes, I refer my students to a colleague who can help them with the issue. & 1 & 2 & 3 & 4 & 5 \\
\hline 21 & $\begin{array}{l}\text { I keep respect for all my colleagues in institution even if they may not be a competent teacher in the view of institution or } \\
\text { the students. }\end{array}$ & 1 & 2 & 3 & 4 & 5 \\
\hline 22 & I try to get some feedback about my colleagues through asking my students. & 1 & 2 & 3 & 4 & 5 \\
\hline 23 & I assess my students based on contents and topics I teach or introduce in class. & 1 & 2 & 3 & 4 & 5 \\
\hline 24 & My final exams include around $80 \%$ of the whole score for the course. & 1 & 2 & 3 & 4 & 5 \\
\hline 25 & I have a non- biased assessment in my classes even for the courses that are not assessed objectively in nature. & 1 & 2 & 3 & 4 & 5 \\
\hline 26 & I try to be respectful to determined rules in the institutions I teach even if the pay does not satisfy me or is not in time. & 1 & 2 & 3 & 4 & 5 \\
\hline 27 & I try to attend my classes on time. & 1 & 2 & 3 & 4 & 5 \\
\hline 28 & I try not to leave my classes before the determined time. & 1 & 2 & 3 & 4 & 5 \\
\hline 29 & I try to make a pleasant atmosphere in my classes. & 1 & 2 & 3 & 4 & 5 \\
\hline 30 & I try to preserve my class dignity. & 1 & 2 & 3 & 4 & 5 \\
\hline 31 & Whenever I attend my classes, I try to forget my outside world concerns. & 1 & 2 & 3 & 4 & 5 \\
\hline 32 & I like to know about views and comments of my students' parents on my teaching. & 1 & 2 & 3 & 4 & 5 \\
\hline
\end{tabular}

\section{What are your opinions as a teacher toward commitment to professional ethics? ( 100 words)}

\begin{tabular}{|l|l|}
\hline Principle 1:Content Competence & items: $1,2,3,4$ \\
\hline Principle 2: Pedagogical Competence & items: $5,6,7,8$ \\
\hline Principle 3: Dealing with Sensitive Topics & items: 9,10 \\
\hline Principle 4: Student Professional Development & items: $11,12,13,14$ \\
\hline Principle 5: Dual Relationship with Students & items: 15, 16, 17, 18 \\
\hline Principle 6: Respect for Colleagues & items: $20,21,22$ \\
\hline Principle 7: Valid Assessment of Students & items: $23,24,25$ \\
\hline Principle 8: Respect for Institution & items: $26,27,28$ \\
\hline Principle 9: Respect for Class & items: $29,30,31$ \\
\hline Principle 10: Confidentiality with students \& Collaboration with Parents & items: 19,32 \\
\hline
\end{tabular}

